\title{
FORMOWANIE CHIN JAKO ODPOWIEDZIALNEGO MOCARSTWA GLOBALNEGO
}

Władimir J. Portiakow, Stanowlienije Kitaja kak otwietstwiennoj globalnoj dierżawy, Izdatel'stwo IDW RAN, Moskwa 2013, ss. 240.

Profesor Władimir Portiakow, członek Rosyjskiej Akademii Nauk i redaktor naczelny magazynu „Probliemy Dalniego Wostoka”, to jeden z wybitniejszych ekspertów rosyjskich, od lat zajmujący się Chinami - polityką wewnętrzną i przede wszystkim gospodarką. W ostatnim okresie swoją działalność naukową skoncentrował na polityce zagranicznej Chin i opublikował wiele prac na ten temat.

Recenzowana książka nie jest prostym opisem polityki zagranicznej Chin, ale - jak sam autor pisze - analizą międzynarodowych i wewnętrznych oznak procesów kształtowania Chińskiej Republiki Ludowej jako odpowiedzialnego mocarstwa globalnego. W pracy są przedstawione etapy tego procesu od zimnej wojny i rozpadu ZSRR, kiedy ChRL była jedynie świadkiem i obserwatorem wydarzeń, do okresu współczesnego, kiedy stała się aktywnym uczestnikiem i współtwórcą nowego systemu międzynarodowego demonstrującego na arenie międzynarodowej swoje aspiracje. Takim momentem przełomowym był kryzys finansowy z lat 1997-1998, kiedy to Chiny przedsięwzięły szereg środków, aby zniwelować jego negatywne skutki. Portiakow twierdzi, że ewolucja działań w kierunku większej aktywności międzynarodowej stanowi konsekwencję zmian w Chinach i jest rzeczą naturalną. Chiny skorzystały na procesie globalizacji i otrzymały „gratyfikację”, ale teraz muszą ją spłacić. Mają do spłacenia dług wobec rynków regionalnych i globalnych.

To, że Chiny zmieniły swoją retorykę i w odniesieniu do świata zewnętrznego posługują się sloganem ,partnerskich relacji”, już świadczy o czymś nowym 
i jest to ważny wkład Chin w budowanie nowych relacji międzynarodowych. Jeśli chodzi o sąsiadów, to tutaj przeważa cel budowy bezpiecznego otoczenia i stabilnych, harmonijnych relacji. Te stosunki jednak psuje spór na Morzu Południowochińskim. Poprzez wskazanie na nowe, charakterystyczne elementy strategii Pekinu na arenie międzynarodowej Portiakow tłumaczy, jakie warunki powinny być spełnione, aby można było nazwać Chiny mocarstwem odpowiedzialnym.

Książka składa się z ośmiu rozdziałów. W rozdziale pierwszym zatytułowanym Formowanie Chin jako odpowiedzialnego mocarstwa globalnego: chronologia i koncepcje autor przywołuje koncepcje, które były głoszone przez Pekin: „pokojowe wzrastanie” zastąpione następnie przez ,ppokojowy rozwój” i hasło prezydenta Hu Jintao „harmonijnego świata”. Po raz pierwszy użyto sformułowania „odpowiedzialne mocarstwo” w roku 1999, ale pojawiła się też informacja nawiązująca do wcześniejszych strategii, związanych z pełnieniem funkcji lidera trzeciego świata - „odpowiedzialne, wielkie mocarstwo rozwijające się”. W pierwszym rozdziale Portiakow śledzi proces postrzegania przez Chiny własnej roli w świecie od 1971 r. (jako członek ONZ), poprzez reformy 1978 r., rok 1986, kiedy ChRL po raz pierwszy oficjalnie zgłosiła chęć akcesji do GATT, uczestnictwo w $1989 \mathrm{r}$. w misjach pokojowych ONZ, następnie przystąpienie do układów o nierozprzestrzenianiu broni atomowej (1992) i innych umów międzynarodowych, wzięcie odpowiedzialności za zakończenie kryzysu finansowego w 1997 r., wreszcie udział Chin w szczytach G8 i G20. Wśród państw pojawiała się też teza, że chciałyby widzieć Chiny jako mocarstwo odpowiedzialne.

Portiakow pisze, że taka ewolucja jest prawidłowa ze względu na gwałtowny rozwój ekonomiczny Chin i jego wskaźniki. Ponieważ udział Chin w gospodarce światowej jest tak duży i stale rośnie, eksperci coraz częściej mówią o znaczeniu Chin, o tym, że powinny wziąć one na siebie odpowiedzialność za system międzynarodowy. $Z$ drugiej strony niektórzy Chińczycy powtarzają, że Chiny nie są na to gotowe, że wciąż jeszcze powinny pełnić funkcję obserwatora, a nie kreatora. Obecnie najbardziej widoczna rola odpowiedzialnych Chin przejawia się w sferze działalności w organizacjach międzynarodowych, w zapewnieniu bezpieczeństwa, budowie gospodarki światowej i przeciwdziałaniu zmianom klimatycznym. Teraz, jak postuluje autor, Chiny powinny poszerzać sfery odpowiedzialności.

Rozdział drugi zatytułowany jest Wewnętrzne mierniki globalnej odpowiedzialności Chin. Autor zwraca tu uwagę na fakt, że odpowiedzialne Chiny to umiejętne połączenie wewnętrznych i zewnętrznych polityk. Wewnętrzna polityka musi stanowić podstawę do odpowiedzialnych zachowań na arenie międzynarodowej. Portiakow przywołuje reformy polityki społecznej. Widoczna jest szersza pomoc socjalna, zabezpieczenie dla ludzi starszych. Model wzrostu ekonomicznego wymaga troski o środowisko i źródła energii. Autor uważa, że w niektórych gałęziach 
przemysłu trzeba przejść na bardziej ekstensywny rozwój. Mowa jest też o konieczności doskonalenia instytucji politycznych. Potrzebna jest reforma systemu administracyjnego kraju. Zachód nawołuje do przestrzegania praw człowieka, ale w tej dziedzinie zrobiono pewien postęp i widoczna jest większa otwartość, ukazuje się periodyk „Prawa Człowieka w Chinach” oraz tzw. białe księgi, gdzie uwzględniane są niektóre niedostatki w tym zakresie.

W rozdziale trzecim, który nosi tytuł Międzynarodowe gospodarcze aspekty osiagnięcia przez Chiny statusu mocarstwa globalnego, autor wychodzi od podstawowej tezy, że aby mówić o odpowiedzialności, kraj musi się dostosować do reguł gospodarczych rządzących światem. Chiny pną się szybko do góry w różnych rankingach. W grudniu 2001 r. stały się członkiem WTO, ale mimo to liczba śledztw dotyczących stosowania cen antydumpingowych nie maleje. Przyjęto również zasadę, że jeśli eksport Chin będzie rósł zbyt szybko, można będzie zastosować określone środki obronne. I tak Portiakow zwraca uwagę, że w tym zakresie nie do końca można liczyć na odpowiedzialność Chin, ponieważ najczęściej przyjmują postawę dla nich korzystną - ,pragmatyczno-egoistyczną”. W obecnym kryzysie Chiny przedsięwzięły szereg środków, aby stymulować wewnętrzne zapotrzebowanie, co jest zjawiskiem pożądanym, ale powinny przejść do „pokryzysowego modelu" odpowiedzialności. Portiakow podkreśla, że optymalnym modelem byłoby samoograniczanie - spowalnianie tempa wzrostu, przede wszystkim jeśli chodzi o ekspansję na rynkach światowych, usług, siły roboczej oraz włączenie zagranicznych źródeł do obsługi gospodarczego wzrostu kraju.

Rozdział czwarty zatytułowany jest Zewnętrzno-polityczne instrumenty Chińskiej Republiki Ludowej: partnerstwo, dobrosasiedztwo, stanowisko przyjmowane w Organizacji Narodów Zjednoczonych. Instrumenty, które autor wymienia w tym rozdziale to: partnerstwo, dobrosąsiedztwo, działalność w ONZ. Formuła partnerstwa ma się przyczyniać do stworzenia sprzyjającej atmosfery od razu na kilku frontach. Polityka dobrosąsiedztwa łączy się z partnerstwem. Ta polityka przyniosła pozytywne rezultaty, bo Chiny rzeczywiście polepszyły relacje z sąsiadami, poczynając od Rosji i Indii, a dodatkowo, jak pisze Portiakow, poprawiła obraz Chin w świecie. Są tu i niedostatki, np. problem archipelagów na Morzu Południowochińskim.

Jeśli chodzi o działalność w ONZ, to pożądane byłyby takie działania, jak: pomoc krajom biednym, oszczędne i odpowiedzialne stosowanie prawa weta, udział w tych inicjatywach ONZ, które są związane z zabezpieczeniem pokoju światowego, płacenie składek, które ze strony Chin rosły, udział w operacjach pokojowych, ewolucja w podejściu do reformy ONZ. Portiakow podkreśla, że widoczna jest wola polepszenia wizerunku Chin na arenie międzynarodowej za pomocą soft 
(miękkiej) i smart (kompetentnej) siły. Pojawia się również, wcześniej nieobecna, dyplomacja innowacyjna.

Rozdział piąty dotyczy dyplomacji ekonomicznej. Jest ona stosowana na przykład wobec Tajwanu. Tutaj autor pisze o dyplomacji naftowej, inwestycjach zagranicznych, dyplomacji z wykorzystaniem instrumentów finansowych. Chiny uczestniczą w szczytach i konferencjach różnych organizacji gospodarczych, choć efekty spotkań nie zawsze są pozytywne. Niekiedy oczekiwania są dużo większe, tak jak chociażby w przypadku szczytów azjatyckiego forum Boao, które miały się stać analogią do światowego forum w Davos, ale takiego znaczenia nie osiągnęły. Portiakow zwraca również uwagę na brak konsekwencji, ponieważ niekiedy priorytety zmieniają się w zależności od bieżących potrzeb kraju. W tej dziedzinie dyplomacja ekonomiczna kraju potrzebuje bardziej wysublimowanej, ale i konsekwentnej realizacji celów długoplanowych, żeby Chiny można było nazwać globalnym i odpowiedzialnym mocarstwem.

Rozdział szósty poświęcony jest Szanghajskiej Organizacji Współpracy oraz roli, jaką odgrywają w niej Chiny i Rosja. Między państwami Azji Środkowej, byłymi państwami związkowymi ZSRR stosunki nie są łatwe, ale SOW sprzyja zbliżeniu. Omówione są tu potencjalne scenariusze rozwoju tej organizacji.

Kolejny, siódmy rozdział poświęcony jest zagadnieniu wielobiegunowości w Rosji i Chinach oraz wyzwaniom międzynarodowym. Jak jest rozumiany świat wielobiegunowy i jaka była ewolucja jego idei? Autor rozpatruje pięć wariantów wyłaniającego się systemu międzynarodowego. Wariant pierwszy to zachowanie dominacji USA, ze względu na zachowanie supremacji amerykańskiej w sferze militarnej, finansowej i możliwą odbudowę pozycji gospodarczej. Wariant drugi to dwubiegunowość lub grupowa dwubiegunowość, np. Zachód - nie-Zachód lub USA, Europa, Japonia, a z drugiej strony BRICS. Wariant trzeci został nazwany minimalną wielobiegunowością, a kandydaci do biegunów to: USA, Chiny oraz Europa. Wariant czwarty to naturalna wielobiegunowość z USA, Chinami, Rosją, Indiami, Japonią, Brazylią i UE. Wreszcie ostatni to rozszerzenie wielobiegunowości na bazie np. G20. Wariant czwarty został wskazany przez autora jako najbardziej prawdopodobny.

W rozdziale ósmym, zatytułowanym $O$ niektórych specyficznych cechach polityki zagranicznej Chin w latach 2009-2011, autor podkreśla, że obecnie Chiny działają na arenie międzynarodowej z większą determinacją i konsekwencją oraz mają osiągnięcia, a to dzięki pozycji na rynkach światowych i stałemu wzrostowi gospodarczemu. Ale zarazem widoczny jest wzrost nacjonalizmu. Chiny jasno wypowiadają się w sprawie konfliktów, które zaistniały w okresie 2009-2010, zmienił się ich stosunek do USA. W niektórych kwestiach były jednak krytykowane, np. wytykano im działania wobec Korei Północnej i brak współpracy z Zachodem 
(od upominania i straszenia KRLD do pomocy wyjścia jej z izolacji politycznej). Specyficzne były też relacje z Japonią, jak i wspomniany już spór z państwami Azji Południowo-Wschodniej, głównie z Filipinami i Wietnamem. Mimo to zewnętrzny kurs polityki chińskiej świadczy o podejściu globalnym, a przykładem jest tu polityka w Afryce i rosnąca aktywność Chin na tym kontynencie. Priorytetem pozostają jednak państwa regionu Azji Południowo-Wschodniej. Jednym z ważniejszych celów polityki Chin i widoczną reorientacją jest priorytetowy charakter stosunków z USA i korekta strategii wobec tego mocarstwa, żeby zniwelować antychiński kierunek polityki amerykańskiej. Z punktu widzenia bezpieczeństwa narodowego ważny jest rosyjski kierunek dyplomacji Państwa Środka.

W zakończeniu książki Portiakow dodaje, że przyjęcie roli mocarstwa odpowiedzialnego, globalnego wymaga pewnych reform i zmian wewnętrznych, wszędzie tam, gdzie mają one wpływ na funkcjonowanie Chin na arenie międzynarodowej. Rosja, jak twierdzi autor - a należy dodać, że nie tylko Rosja - musi znać i rozumieć te procesy. W tej sytuacji dostosowanie Rosji i zaakceptowanie nowego statusu Chin jako globalnego mocarstwa jest według prof. Władimira Portiakowa niezbędne, mimo że dla Rosjan może to być z psychologicznego punktu widzenia bolesny proces. Do niedawna to Rosja (ZSRR) była mocarstwem globalnym i musiała podejmować decyzje, biorąc pod uwagę nie zawsze jedynie własne interesy. W książce autor odpowiada również na szersze pytanie dotyczące teorii odpowiedzialności mocarstw, ich zachowań i warunków, które powinny być spełnione, aby można było nazwać je mocarstwami odpowiedzialnymi. Te ciekawe, niekiedy wymagające wprost polemiki, szerszego komentarza i dyskusji opinie przedstawione w książce polecam wszystkim, którzy interesują się problematyką współczesnych Chin: studentom, ekspertom i naukowcom. Książka zawiera dane z okresu do 2011 r. Warto zaznaczyć, że niemal w całości rozdziały zostały przetłumaczone na język angielski, zatem i ci, którzy nie znają rosyjskiego, mogą sięgnąć po tę publikację. $Z$ pełnym przekonaniem polecam! 